\title{
Praise or Criticism? How Should Teachers Give Effective Feedback in the Classroom Teaching?
}

Fengping Zhao

271 Education Group of Shandong, Weifang 261000, Shandong, China

"Praise like sunlight, helps all things to grow."

- Croft M. Pentz

$\mathrm{T}$

HERE are many factors that affect students' academic performance. Early studies emphasized students' existing foundations, their own abilities (Stigler et al., 1986), family factors (Wang, 2015), school or class organizational structure (Angrist, \& Lavy, 1999; Häkkinen et al., 2003), cultural factors (Geary et al., 1993; Stigler \& Stevenson, 2005) and other influences on their academic performance. However, the research on the influence of teacher factors has only received attention since the 1980s. Researchers explored the relationship between teachers' classroom behavior and students' academic performance, trying to focus on the teaching process (Lockheed \& Komenan, 1989), teacher guidance (Brophy, 1988), teacher feedback (Gettinger, \& Stoiber, 1999), Teacher planning and preparation (Peterson, Marx \& Clark, 1978) explored the causes that can significantly affect students' academic performance.

Teacher feedback is considered to be the behavior that connects all events in the classroom. It provides students with opportunities to participate and makes them perform, and then immediately respond accordingly. Therefore, the two events of student learning behavior and teacher feedback are closely related in time. "The closer the connection between behavior and feedback, the faster learning will happen.” That is, providing feedback is a complete continuation of classroom activities.

In terms of effectiveness, feedback gives students the opportunity to understand the teacher's subjective view of their personal characteristics and school performance. Furthermore, it can update self-cognition and selfevaluation, and help correct and strengthen students' learning in time. Specifically, the effect of feedback on students is mainly reflected in the two aspects of students' academic performance and learning motivation. Butler and Nisan (1986) confirmed that effective or efficient feedback can not only 
guide students in the formulation of learning strategies and the realization of learning goals, but also inspire students' inner emotion and motivation to mobilize various factors to achieve their goals. Finally, it promotes students' meaningful learning. Inappropriate feedback from teachers can cause negative effects. For example, inappropriate feedback causes students to make wrong attributions, causing "learned helplessness" and hindering their development and progress.

As the most common motivational means in teacher teaching management, praise and criticism are both a kind of feedback (Kamins \& Dweck 1999), that is, the teacher (or peers, books, parents, self and experience) provided by the individual performance or understanding Information (Hattie \& Timperley, 2007). From the Skinner reinforcement theory, praise is a positive reinforcement stimulus behavior with affirmative color, while criticism is a negative reinforcement behavior (Skinner, 2019). Generally speaking, affirmative reinforcement helps students to actively accept and internalize teachers' requirements, and can mobilize students' learning motivation (Henderlong \& Lepper, 2002). Negative reinforcements make students nervous and produce psychological pressure (anxiety, irritability, restlessness, depression, and even aggressive behavior) (Wei, 2015). But does this mean that teachers should praise instead of criticizing?

Zhang et al. (2021) believed that in classroom teaching, teachers' praise can play a positive role to some extent, but this effect varies with the field of use, personal characteristics of the target, and attribution habits. It presents both shallow and deep effects. The deep effect is that students consolidate their behavior after being praised, and transfer this behavior to other scenes, so that student behavior can be further strengthened. The article also starts from Skinner's reinforcement theory, and believes that if a student's behavior that is consolidated by praise is not reinforced within a certain period of time, this behavior will naturally weaken and gradually fade away. In order to avoid the natural regression of reinforcement behavior, teachers should pay attention to phased reinforcement, that is, partial reinforcement. At the same time, teachers should start from behaviorist theory and avoid frequent and superficial praise; on the contrary, they should attract students through education and teaching activities, so that students can truly feel the needs and satisfaction of learning, and then consciously participate in education and teaching activities. Finally realize the deep effect of feedback.

Although the article does not discuss criticism, it is not difficult to find in the relevant literature that there are also many studies on criticism as the “opposite” of praise. From the perspective of teachers' feedback behavior, criticism and praise are mutually integrated and connected behaviors, both of which are behaviors that discipline students (Yao et al., 2020). Teachers should not only pay attention to the multi-frequency and shallow level of praise in the praise, but also criticize the students. It is important for teachers to give encouraging answers to wrong answers, so as to maintain the nonevaluative characteristics of the triggering activity. 
In general, encouraging positive feedback should look at characteristics from things to people and behaviors. Negative judgment feedback should be from people to things, affirm the people's strengths, and then point out the problems. Praise and criticism are not two opposites. Both should be properly presented in the teacher's feedback in the classroom, giving signals from different aspects of the continuation or change of student behavior. The key is to have justified, true and emotional praise and criticism.

\section{References}

Angrist, J.D., \& Lavy, V. (1999). Using Maimonides' rule to estimate the effect of class size on scholastic achievement. The Quarterly Journal of Economics, 114(2):533575 .

Brophy, J. (1988). Research linking teacher behavior to student achievement: Potential implications for instruction of Chapter 1 students. Educational Psychologist, 23(3):235-286.

Butler, R., \& Nisan, M. (1986). Effects of no feedback, task-related comments, and grades on intrinsic motivation and performance. Journal of Educational Psychology, 78(3):210.

Geary, D.C., Bow-Thomas, C.C., Fan, L., \& Siegler, R.S. (1993). Even before formal instruction, Chinese children outperform American children in mental addition. Cognitive Development, 8(4):517-529.

Gettinger, M., \& Stoiber, K.C. (1999). Excellence in teaching: Review of instructional and environmental variables. The Handbook of School Psychology, 3:383-409.

Häkkinen, I., Kirjavainen, T., \& Uusitalo, R. (2003). School resources and student achievement revisited: new evidence from panel data. Economics of Education Review, 22(3):329-335.

Hattie, J., \& Timperley, H. (2007). The power of feedback. Review of Educational Research, 77(1):81-112.

Henderlong, J., \& Lepper, M.R. (2002). The effects of praise on children’s intrinsic motivation: A review and synthesis. Psychological Bulletin, 128(5):774.

Kamins,ML..\&Dweck,C.S.(1999).Person versus process praise and criticism: Implications forcontingent self-worth and coping. Developmental Psychology, 35(3):835847.

Lockheed, M.E., \& Komenan, A. (1989). Teaching quality and student achievement in Africa: The case of Nigeria and Swaziland. Teaching and Teacher Education, 5(2):93-113.

Peterson, P.L., Marx, R.W., \& Clark, C.M. (1978). Teacher planning, teacher behavior, and student achievement. American Educational Research Journal, 15(3):417-432. 
Skinner, B. F. (2019). The behavior of organisms: An experimental analysis. BF Skinner Foundation.

Stigler J.W., \& Stevenson H.W. (2005). How Asian teachers polish each lesson to perfection. Readings on the Development of Children, 236.

Stigler, J.W., Lee, S.Y., \& Stevenson, H.W. (1986). Digit memory in Chinese and English: Evidence for a temporally limited store. Cognition, 23(1):1-20.

Wei, B. (2015). Classroom Perspective: Primary and Secondary School Teachers’ Critical Behavior and Its Impact on Teacher-student Relationship and Student Self-esteem (Master's Thesis, Soochow Universi-

ty). https://kns.cnki.net/KCMS/detail/detail.aspx?dbname=CMFD201601\&filenam $\underline{\mathrm{e}=1015404496 . \mathrm{nh}}$

Yao, D., Xu, Y., \& Zhang, P. (2020). Teacher feedback and students' self-education expectations: The impact of praise and criticism on different students' self-education expectations. Economic Science, 2020(5):111-123.

Zhang, S., Du, X., \& Deng, J. (2021). A mixed study on the effectiveness of verbal praise in primary school class. Science Insights Education Frontiers, 10(1):1353-1363. DOI: https://doi.org/10.15354/sief.21.or060

Correspondence to:

Fengping Zhao

271 Education Group of Shandong

Weifang 261000

Shandong

China

Email: zhaofengping5138@163.com

Conflict of Interests: None.

Doi: 10.15354/sief.21.co024 